\title{
ВПЛИВ СІМЕЙНИХ ПРОБЛЕМ НА ПСИХОЛОГІЧНИЙ СТАН ВІЙСЬКОВОСЛУЖБОВЦІВ ПІД ЧАС АТО
}

На основі огляду наукових джерел та емпіричних досліджень проаналізовано найбільш поширені сімейні проблеми військовослужбовців та їхній вплив на психологічний стан бійців під час виконання ними службових завдань у зоні проведення АТО. Значення “стресорів сімейного життя” порівнюється 3 іншими стресогенними чинниками для військовослужбовців, які брали безпосередню участь у бойових діях і перебували в зоні проведення АТО понад 6 місяців, та військовослужбовців, які участі в бойових діях не брали, але тривалий час виконували завдання в зоні проведення АТО. 3'ясовано, що обидві категорії досліджуваних більш чутливі до сімейних стресорів, ніж до поганих гігієнічних умов, довготривалих навантажень, неочікуваної зміни умов служби, міжособистісних конфліктів та недостатнього задоволення біологічних і соціальних потреб. Виявлено, що серед чинників, які впливають на психологічний стан військовослужбовців, сімейні стресори не витісняються як незначущі 3 переліку інших. За результатами інтерв'ювання військових психологів та капеланів на тему сімейних проблем у родинах військовослужбовців, учасників ATO окреслено коло найбільш поширених проблем у родинних стосунках та розкрито їхній вплив на психологічний стан військовослужбовців на різних етапах виконання службово-бойового завдання в зоні АТО (під час перебування в АТО, після повернення додому). Зроблено висновок, що гармонійні стосунки в сім'ї військовослужбовця стають для нього підтримувальним чинником під час служби і ресурсом у період відновлення. Водночас зауважено, що напружені, конфліктні стосунки між подружжям деструктивно впливають на психологічний стан військовослужбовців під час служби (депресивні стани, зловживання спиртними напоями, агресивність, замкненість, порушення статуту, суїцидальні думки тощо) і не сприяють відновленню в періоди між службовими завданнями. Щоб запобігти виникненню перелічених труднощів у родинах військовослужбовців, запропоновано завчасно інформувати їх та членів їхніх родин про можливі зміни в стосунках та надавати психосоціальну підтримку на кожному з етапів для своєчасного виявлення і корекції такого роду проблем.

Ключові слова: АТО, родина військовослужбовця, сім'я учасника АTO, соціально-психологічна підтримка, психологічний стан військовослужбовця, сімейні стосунки, комбатанти.

\section{N. F. Didyk}

\section{THE INFLUENCE OF FAMILY PROBLEM ON THE PSYCHOLOGICAL STATE OF THE SERVICEMEN DURING ATO}

On the basis of scientific sources and empirical studies it is made the analysis of the peculiarities of family problems and their influence on the psychological state of servicemen during their ATO service. The significance of "stressors of family life" is analyzed in comparison with other stress factors for servicemen who took part in military operations and were in ATO for more than 6 months, and for 
servicemen who didn't take part in military operations, but for a long time fulfilled other ATO tasks. It is stated that for both studied categories the family stressors are higher than bad hygiene conditions, long-term load, unexpected changes in service conditions, interpersonal conflicts and dissatisfaction with biological and social needs. It was found that among stressors that influence the psychological state of servicemen, the family stressors are not suppressed as insignificant among the other ones. According to the results of military psychologists and chaplains interviewing, concerning the topic of domestic problems in families of ATO participants, there are outlined the most common problems in family relationships and their effect on the psychological state of the servicemen on different stages of implementation of military and combat tasks in ATO zone, (during stay in ATO and after returning home). It is concluded that harmonious relations in the serviceman family become a supporting factor for him during the service and the resource during the restoration. At the same time it is noted that conflict relations between spouses destructively affect the psychological state of servicemen during service (depressive states, alcohol abuse, aggressiveness, secrecy, violation of the statute, suicidal thoughts, etc.) and do not facilitate the restoration between military tasks. In order to prevent the emergence of most problems in the families of servicemen, it is proposed in advance to inform them and their families about possible changes in relationships and provide them with psychosocial support at each stage for in-time detection and correction of outlined problems.

Key words: ATO, family of a serviceman, family of ATO participant, sociopsychological support, psychological state of a serviceman, family relationships, combatants.

Постановка проблеми. 3 виникненням у квітні 2014 р. воєнного конфлікту на сході України, визначеного нормативними актами як антитерористична операція (далі - АТО), підрозділи Збройних сил України (ЗСУ) та Національної гвардії України (НГУ) постійно залучаються до виконання службових завдань у зоні проведення АТО. Як правило, такі завдання мають різну тривалість (3-6 місяців і більше) та періодичність і передбачають віддалене перебування військовослужбовців від місця проживання їхніх сімей.

Тривання воєнних дій п'ятий рік поспіль так чи інакше відображається на психологічному стані діючих військовослужбовців та їхніх рідних і близьких. Постійне хвилювання членів сімей військовослужбовців за їхнє життя та здоров'я, постійний перезапуск стосунків між відрядженнями, адаптація до нових форм поведінки подружжя після повернення і перед відбуттям військових у зону АТО - усе це породжує серйозні виклики для сімейних стосунків у родинах військовослужбовців.

Гармонійні стосунки в сім’ї - це важливий додатковий ресурс, коли йдеться про підтримку психічного здоров'я військовослужбовців. Разом 3 тим сімейні проблеми, які можуть виникати на тлі тривалих стресових станів подружжя, здатні суттєво вплинути на психологічний стан військового, а то й обернутися негативними наслідками для його здоров'я і навіть життя. За словами керівника управління моральнопсихологічного забезпечення ЗСУ, “серед осіб, які вчинили самогубство 
в армії, більшість тих, хто не витримує психологічного тиску соціальних та побутових проблем, з якими доводиться стикатися його сім’і, особливо коли сімейні проблеми пов'язані 3 його тривалою відсутністю вдома, у той момент, коли військовий служить і не може приділити близьким достатньої уваги" [1]. За офіційними даними, наразі Збройні сили України налічують у своїх лавах 255 тис. військовослужбовців, 3 яких протягом останніх двох років 130 тис. осіб уклали контракт. Переважно це люди, які вже виконували службово-бойові завдання в зоні бойових дій [2].

В Україні у зв'язку з воєнними подіями на сході також стрімко зростає актуальність підтримки сімей у процесі реінтеграції, реадаптації та реабілітації військовослужбовців - учасників АТО. Відповідно до Постанови Кабінету Міністрів України № 528 від 2017 р. системна оцінка потреб сімей учасників АТО, надання соціальних послуг, супроводу, послуг із соціальної інтеграції та реінтеграції, кризового та екстреного втручання, забезпечення психологічної підтримки покладаються на місцеві центри соціальних служб для сім’і, дітей та молоді. Ці центри забезпечують виконання покладених на них місцевими програмами обов'язків [3]. Утім, соціальні служби, підпорядковані Міністерству соціальної політики, охоплюють насамперед ветеранів. Водночас особливо гостро постає питання психосоціальної роботи із сім'ями діючих військовослужбовців. Така робота передбачає аналіз впливу сімейних проблем на психологічний стан військових, своєчасне виявлення та корекцію цих проблем, у тому числі під час активних бойових дій.

Аналіз останніх досліджень і публікацій. Особливості впливу сім'ї на психологічний стан військовослужбовця під час відбування ним служби та після завершення службово-бойового завдання вивчали як зарубіжні [4], так і вітчизняні фахівці. Вітчизняні дослідження проблем психосоціального забезпечення діяльності військових підрозділів показують, що для психологічного стану військових як на стадії виконання бойового завдання [5], так і після його завершення [6] важливе значення мають стосунки 3 найближчим оточенням, а саме із членами сім'ї. Гармонійні стосунки в родині $є$ тим чинником, який здатний істотно зменшити ризик виникнення ПТСР [7]. Згідно з результатами досліджень українських фахівців, після повернення із зони бойових дій військовослужбовець так само потребує підтримки дружини, матері і свого командира [8]. Ми цілком погоджуємося 3 думкою дослідників, що забезпечення психічного здоров'я військовослужбовців та членів їхніх сімей $є$ запорукою успішного виконання військовими формуваннями України поставлених перед ними завдань [9].

Не вирішені раніше частини загальної проблеми. На сьогодні недостатньо досліджено, як на психологічний стан бійців впливають сімейні проблеми, з якими стикається родина військовослужбовця на 
різних етапах виконання ним службово-бойового завдання в зоні воєнного конфлікту (перед відправленням туди, під час перебування там i після повернення додому). Саме тому ми вирішили з'ясувати, яким чином сімейні проблеми впливають на психологічний стан військовослужбовців під час АТО, що, відповідно, може надалі допомогти проводити роботу з коригування наявних проблем та психосоціальну роботу, спрямовану на запобігання цим проблемам.

Метою статті $\epsilon$ аналіз найбільш поширених сімейних проблем військовослужбовців та їхнього впливу на психологічний стан бійців під час виконання ними службових бойових завдань в зоні АТО на основі огляду наукових джерел та емпіричних досліджень.

Виклад основного матеріалу дослідження. У цій статті ми вирішили відійти від загального огляду сімейних проблем військовослужбовців на трьох етапах (перед АТО, під час АТО та після повернення додому) виконання ними бойового завдання, які ми визначили в попередньому дослідженні [10]. Етап “перед відбуттям у зону АТО" нас наразі цікавить менше, оскільки всі військовослужбовці, які постійно виконують завдання в зоні АТО, перебувають на службі за контрактом. Тому між етапами "перед відбуттям в АТO" та етапом "після повернення з АТО" досить незначний проміжок часу (залежно від роду військ), і вони практично переходять один в одний. Ми зосередимо увагу лише на двох із них, а саме: “під час перебування в АТО" і “після повернення додому", оскільки саме під час перебування в зоні проведення АТО військовослужбовці зазнають впливу екстремальних умов та різного рівня стресу, а після повернення додому проходять етап відновлення перед виконанням наступних службових завдань.

У розвинених країнах світу, зокрема в США та Канаді, діють державні програми підтримки сімей військовослужбовців на різних етапах розгортання військових підрозділів (перед розгортанням, під час розгортання та після повернення на етапі возз'єднання сім'ї). Ці програми стосуються як членів сім'ї військового, так і самого військового безпосередньо [4].

Діагностика негативних психічних станів військовослужбовців передбачає врахування специфіки дії на них різного плану стресорів: стресорів короткочасної дї (від декількох годин до декількох діб), стресорів тривалої дї (від декількох місяців до декількох років), сnецифічних бойових стресорів, які мають підвищений рівень стресогенності, неспецифічних, до яких належать стресори, характерні як для бойової обстановки, так і для інших видів стресових ситуацій [11, с. 5]. Зокрема, до стресорів довготривалої дії, окрім інших чинників, належить служба у військових підрозділах, пов'язана з тривалим відривом від сім'ї та звичних умов, тривалими відрядженнями в район бойових дій та ін. $[11$, с. 6]. 
Спираючись на дослідження наших колег, спробуймо з'ясувати, яке місце посідають стресори, пов'язані із сім'єю. У зв'язку із цим заслуговують на увагу дослідження Науково-дослідного центру гуманітарних проблем Збройних сил України щодо особливостей негативних психічних станів у військовослужбовців (2 і 3-тя хвилі мобілізації) внаслідок тривалої участі в бойових діях та перебування в зоні АТО [10], зокрема результати, отримані за методикою "Стрес-фактори" [12, с. 7]. На основі цієї методики аналізується вплив стресогенних чинників на дві вибірки: 1) на військовослужбовців, які брали безпосередню участь у бойових діях і перебували в зоні проведення АТО понад 6 місяців (22 респонденти, далі - вибірка “бійці”); 2) на військовослужбовців, які участі в бойових діях не брали, але тривалий час виконували завдання в зоні проведення АТО (54 респонденти, далі - група “учасники"). Ми не будемо тут аналізувати всі результати, отримані за згаданою методикою, а звернемо увагу лише на вплив стресогенного чинника “стресори сімейного життя". Із 30-ти можливих балів для групи "бійці" сила впливу иього чинника становила 13,35 бала, для групи “учасники” - 14,82. Як бачимо, для групи учасників цей показник дещо вищий, ніж для групи бійців.

Дослідники відносять вплив стресогенного чинника "стресори сімейного життя" до таких, що виражені середньою мірою. Найбільш стресогенними для всіх досліджуваних (20,6 - 22,9 бала за умови максимальних 30 балів) виявилися: “страх полону”, “захоплення в полон бойових побратимів, товаришів”, “події, у результаті яких постраждали честь і достоїнство”, “ситуації, які загрожують життю та фізичній цілісності”, “помилки командування”, “поранення, контузії, каліцтва”, “випадки загибелі мирних громадян, побратимів”, “страхітливі картини смерті, людські втрати та муки”, “побоювання, страх власної загибелі”, “досвід невдалих дій”, “стресори морального характеру”, “контакт 3 великою кількістю поранених”.

Відтак порівняймо вагомість чинника "стресори сімейного життя" 3 вагомістю інших чинників.

Для групи “учасники” чинник “стресори сімейного життя” має приблизно таку ж саму вагомість (у балах), як чинники:

- “довготривале виконання роботи, яка вимагає напруження; підвищена відповідальність за свої діі” - 14,96;

- “незадоволеність матеріальних потреб” - 13,79;

і перевищує вагомість чинників:

- “погані гігієнічні умови” - 13,13;

- “довготривалі навантаження, які породжують втому” - 11,27;

- “сексуальна дисгармонія" - 11,22;

- “незадоволеність біологічних і соціальних потреб” - 10,96;

- “інтенсивні міжособистісні конфлікти” - 10,76; 
- “різкі, неочікувані зміни умов служби” - 10,37.

Для групи “бійці” стресори сімейного життя перебувають практично за вагомістю на одному рівні з чинниками:

- "стресор морального характеру (докори совісті, відповідальність за життя невинних людей, необхідність застосування зброї та інших засобів ураження)" - 13,65;

- “незадоволеність біологічних і соціальних потреб”- 13,41;

- “фізичне знищення бойовиків (особливо вперше)” - 13,35;

- “сексуальна дисгармонія" - 13,27;

і перевищує вагомість чинників:

- “контакт з великою кількістю поранених" - 12,86;

- “різкі, неочікувані зміни умов служби” - 12,71;

- “довготривале виконання роботи, яка вимагає напруження, підвищена відповідальність за свої дії” - 12,19;

- “погані гігієнічні умови" - 9,91;

- “вигляд трупів, крові” - 9,81;

- “незадоволеність матеріальних потреб” - 9,45;

- “інтенсивні міжособистісні конфлікти” - 9,20.

Якісний порівняльний аналіз показав, що і в “учасників", і в “бійців" сімейний чинник перевищує за вагомістю "погані гігієнічні умови”, “довготривалі навантаження, які породжують втому”, “сексуальну дисгармонію”, “інтенсивні міжособистісні конфлікти”, “незадоволеність біологічних і соціальних потреб”, “різкі, неочікувані зміни умов служби". Хоч, здавалося б, чим більше у “бійців" стресових перевантажень, пов'язаних із загрозою життю, тим більше сімейний чинник мав би відходити на задній план. Проте, як бачимо, у “бійців" стресор сімейних стосунків залишається на рівні з факторами "фізичне знищення бойовиків (особливо вперше)”, “незадоволеність біологічних і соціальних потреб” та "стресор морального характеру (докори совісті, відповідальність за життя невинних людей, необхідність застосування зброї та інших засобів ураження)" і навіть дещо перевищує за значущістю "контакт з великою кількістю поранених" та “вигляд трупів, крові”. Також у “бійців" порівняно з “учасниками" дія сімейного стресора виявляється сильніше, ніж “довготривале виконання роботи, яка вимагає напруження, підвищена відповідальність за свої діі”' і “незадоволеність матеріальних потреб".

Отже, попри те, що в “учасників" показники сімейних стресорів вищі, ніж у “бійців", якісний порівняльний аналіз засвідчив, що в останніх сімейні стресори не втрачають своєї вагомості, а навпаки, вона в них дещо зростає, порівняно 3 тими чинниками, що мали меншу вагомість для “учасників". 3 огляду на це можемо зробити висновок, що сімейні стресори не витісняються як незначущі з переліку інших. Проблема сімейних стосунків і сімейних стресорів не втрачає своєї актуаль- 
ності для учасників бойових дій, хоч захисна реакція на тлі травматичних подій і могла б створити ілюзію, що ці стресори стають менш важливими.

Щоб охарактеризувати особливості сімейних проблем та уявлення про їхній вплив, ми провели емпіричне дослідження у вигляді глибинних інтерв'ю та розглянули проблеми на різних етапах виконання завдань в АТО: окремо - під час перебування військовослужбовців у зоні АТО, й окремо - після повернення їх з АТО. Опитано 13 респондентів, 3 них 6 - жінки і 7 - чоловіки. Серед опитаних 10 офіцерів-психологів НГУ (4 чоловіків і 6 жінок; 7 з них мають досвід особистого перебування в зоні АТО; всі психологи мають досвід роботи з військовослужбовцями, які відбувають службу в зоні АТО, і членами їхніх сімей); 2 військових капелани НГУ (мають досвід служби в зоні АТО й працюють і далі з військовослужбовцями та членами їхніх родин). Крім того, аналіз включав інтерв'ю з військовослужбовцем - учасником АТО, чий окремий випадок становить інтерес, оскільки проблеми, які виникли в подружніх стосунках військовослужбовця під час перебування в зоні АТО, призвели до руйнування його сім'ї та розлучення. Усі респонденти були одружені та мали різний рівень вияву перелічених проблем у власних родинах; 11 з 13-ти мали дітей (дошкільного та шкільного віку). Вік респондентів становив 30-45 років [10].

Розгляньмо відтак перший етап - niд час перебування в зоні АTO (одне відрядження триває зазвичай 2-3 місяці). Офіцери-психологи та капелани зазначили, що на цьому етапі важливу роль відіграє емоційний стан військовослужбовця - настрій, з яким він залишив родину та прибув для виконання службово-бойового завдання. Протягом перших кількох днів уся увага військовослужбовця максимально спрямована на прийняття службових обов'язків від колег, які їдуть на ротацію. Паралельно, саме в ці перші 7-10 днів, родина переживає адаптацію та найбільший стрес за відсутності військовослужбовця вдома. У цей час в комунікації між подружжям може спостерігатися напруженість через взаємні невиправдані очікування щодо емоційної підтримки одне одного, що, як вважають опитані, впливає на психоемоційний стан військовослужбовця.

Також респонденти відмічають, що в сім'ях, де ще до відрядження спостерігалися напружені стосунки, можуть виникати недовіра, страх зради, відбуватися алкоголізація чоловіка. Усе це виливається відтак у телефонні конфлікти. На думку опитаних, такі конфлікти часто тягнуть за собою агресивну поведінку військового в місці відбування служби, порушення наказів керівництва і статутних норм, зловживання спиртними напоями, самоушкодження i, як крайню форму, спроби самогубства.

Якщо у подружжя до відрядження були нормальні стосунки, вони стають підтримувальним чинником для військових. Зазвичай у таких військовослужбовців актуалізується лише хвилювання за здоров'я рідних, 
поведінку дітей у школі та матеріальне забезпечення родини. Про всі ці моменти подружжя спілкується телефоном i, залежно від обставин, у чоловіка або виникають хвилювання, сум, дезорієнтація, розпач (оскільки він нічого не може зробити, аби зарадити посталій удома проблемі), або він спокійний, оскільки вдома все гаразд. Якщо до відрядження стосунки в родині були нормальні, як правило, страх зради не гнітить чоловіка, за винятком хіба що молодих військовослужбовців, які нещодавно одружилися.

У цілому, говорячи про сімейні проблеми в родинах військовослужбовців під час даного етапу, респонденти зазначали, що важливо своєчасно виявляти напруженість у сімейних стосунках військовослужбовця та вчасно ії коригувати. На думку військових психологів та капеланів, завчасне інформування військовослужбовців і членів їхніх родин про можливі зміни в стосунках та надання відповідних рекомендацій (наприклад, у форматі буклетів, інформаційних зустрічей тощо) здатні запобігти виникненню більшості проблем у родинах військовослужбовців [10].

Отже, важливо проводити серед військовослужбовців, у тому числі безпосередньо в зоні виконання ними службово-бойового завдання, своєчасну просвітницьку і психосоціальну роботу щодо сімейних проблем. Так само під час перебування військового в зоні АТО важливо проводити інформаційну роботу з членами його родини за місцем їхнього проживання: інформувати про особливості психоемоційних станів військовослужбовця під час перебування в зоні АТО, акцентувати увагу на особливостях спілкування з військовим телефоном і за допомогою соціальних мереж, надавати психосоціальну та психологічну підтримку дружинам, якщо в них виникають складні емоційні стани або якісь проблеми з дітьми.

Структуруючи відповіді респондентів щодо сімейних проблем на етапі після повернення з АTO, можна виокремити такі найпоширеніші 3 них: напружені стосунки через замкненість і відчуженість чоловіка та страх дружини через незвичні вияви поведінки чоловіка; холодність у стосунках між батьком і дитиною; порушення інтимних стосунків, брак часу на дозвілля з родиною між службово-бойовими завданнями [10].

3 досвіду психологів, військовослужбовці, перебуваючи у зоні бойових дій, переживають ті чи інші стресові ситуації. Навіть ті з них, які не перебувають у першій лінії оборони, а відбувають службу на 2 або 3-й лінії, постійно відчувають емоційне напруження, оскільки обставини воєнного конфлікту на сході України наразі непередбачувані. Переживання емоційного напруження, бойового стресу, посттравматичного стресового розладу [5; 13] викликає у військовослужбовця бажання відсторонитися від близьких, аби їм не нашкодити; уникати вияву емоцій у присутності рідних; відійти від побутових питань, 
оскільки з'являється відчуття своєї непотрібності; втамувати біль алкоголем тощо.

Дружини таких військовослужбовців, спілкуючись із фахівцями, часто зізнаються в тому, що їхні чоловіки після кожного такого чергового відрядження повертаються 3 новими виявами поведінки, і сім'я змушена щоразу адаптуватися по-новому. Під час кожної такої адаптації родина переживає стрес, що викликає напруження в стосунках. У сім'ях, де добре налагоджена комунікація, цей процес проходить легше і швидше.

Окремою важливою проблемою, що потребує уваги, є порушення інтимних стосунків. За словами опитаних (зокрема жінок), інтимні стосунки подружжя після повернення чоловіка із зони бойових дій змінюються. Фахівці з огляду на досвід спілкування з дружинами військових відмічають, що протягом першого тижня після повернення чоловіка додому у нього спостерігається або надмірний статевий потяг, або ж цей потяг зникає. Часто також простежується втрата ніжності в стосунках, що в подальшому може призвести до відмови від інтимних стосунків на тривалий час. Особливо це стосується тих подружніх пар, де чоловік постійно їздить у відрядження в АТО (термін кожного такого відрядження - 2-3 місяці). Такі зміни як чоловіки, так і дружини часто інтерпретують як згасання почуттів або привід для ревнощів та хвилювань, що, зрозуміло, породжує конфлікти і деструктивно впливає на психологічний стан військового.

За словами респондентів-чоловіків, повертаючись додому з відрядження, вони очікують, що дружина і діти будуть їх радісно зустрічати та безумовно приймати всі вияви їхньої поведінки. Разом 3 тим існує хвилювання, як зустріне тата дитина, чи впізнає вона його (якщо дитині до 3-х років). Особливо гостро це питання хвилює військовослужбовців, які у відрядженні вже не вперше і мають досвід відстороненості дитини від батька одразу після повернення того додому. I коли позитивні очікування не справджуються через емоційні стани членів сім’ї (які $є$ нормальними для них на той час), чоловіки відчувають спустошеність і сум, збурення емоцій, переймаючись думкою, що на них не чекали і їх не раді бачити. Зрозуміло, такі стосунки в сім’ї після повернення чоловіка додому не сприяють відновленню психологічного стану військовослужбовця та його підготовці до виконання наступних службово-бойових завдань.

Однією 3 основних рекомендацій самих респондентів щодо запобігання виникненню вищезазначеної проблеми в подружніх стосунках на цьому етапі $є$ попереднє інформування як дружин, так i військовослужбовців про можливі зміни в інтимному житті, про зміни емоційних станів дітей та рекомендації, як варто реагувати на ці зміни. Для чоловіків роз'яснення щодо даної теми можна проводити як перед відбуттям у зону виконання бойового завдання, так і актуалізовувати 
інформацію перед поверненням додому, надаючи інформаційний буклет, що містить рекомендації та корисні контакти.

Отримані нами дані підтверджують загальну тенденцію, яку відмічають інші дослідники. Роль сім'ї як післястресового оточення фахівці визнають важливою як у виявленні порушень унаслідок травми, у протидії травмі, так і в полегшенні відтворення пережитих подій [9].

Незаперечним фактом $є$ і те, що травмування одного члена сім'ї справляє безпосередній вплив на інших. У наукових джерелах описано такі варіанти впливу травми на сім'ю: 1) усі члени родини зазнали впливу події; 2) травмовано члена сім'ї, який перебуває в іншому місці; 3) жертвою стає один член сім'ї, який відтак впливає на інших; 4) травматичний вплив виходить від одного з членів сім'ї. Існування таких взаємовпливів у сім'ях військових підтверджують дослідження американських учених, які виявили високу частоту депресивних тривожних розладів та високий рівень алкоголізації у $68 \%$ членів родин ветеранів війни у В'єтнамі, що мають посттравматичні розлади [14].

Вітчизняні дослідники зазначають, що в частини військовослужбовців розвиток психопатологічних станів пов'язаний із психічною травматизацією внаслідок дії екстремальних чинників під час перебування в АТО. Разом з тим негативні психічні стани розвиваються у військовослужбовців і в період реадаптації до звичайних умов служби, після повернення із зони АТО. Порушення можуть виявлятися на психологічному (поведінковому) рівні у вигляді пригніченого настрою, тривожності, агресивності, депресій, зловживання алкогольними напоями $[11$, с. 10]. Суттєво ускладнюють перебіг постстресових змін, на думку дослідників, додаткові психотравматичні події та несприятливі стосунки в родині [14].

Підсумки нашого дослідження не заперечують, а уточнюють результати, отримані іншими авторами, оскільки характеризують ситуацію наших військових на даному етапі воєнного протистояння агресору.

Висновки. На основі аналізу впливу сімейних проблем на психологічний стан військовослужбовців під час АТО виявлено:

- серед стресорів, що впливають на психологічний стан військовослужбовців, сімейні стресори не витісняються як незначущі з переліку інших. Проблема сімейних стосунків і сімейних стресорів для учасників бойових дій не втрачає своєї актуальності попри те, що захисна реакція на тлі травматичних подій часом створює ілюзію, що ці стресори стають менш важливими;

- у разі напружених стосунків “до АТО” найпоширенішими проблемами в сім'ях під час перебування військовослужбовців в АТО є: недовіра, страх зради, алкоголізація чоловіка, що виливається в телефонні конфлікти, які можуть стимулювати конфліктну, агресивну поведінку військового під час відбування ним служби, порушення 
наказів командирів і статутних норм, зловживання алкогольними напоями, хвилювання, сум, дезорієнтацію, розпач, самоушкодження i, як крайню форму, спроби самогубства (оскільки він нічого не може зробити, аби зарадити посталій удома проблемі);

- у разі нормальних сімейних стосунків “до АТО” сім'я стає ресурсом для військового і тим чинником, який допомагає йому швидше подолати наслідки перебування в екстремальних ситуаціях;

- після повернення військовослужбовців з АТО найпоширенішими проблемами є напружені стосунки подружжя через замкненість та відчуження чоловіка або страх дружини через незвичні вияви поведінки чоловіка; холодність у стосунках між батьком і дитиною; порушення інтимних стосунків, що в сукупності породжує конфлікти і деструктивно впливає на відновлення психологічного стану військового;

- завчасне інформування військовослужбовців та членів їхніх родин про можливі зміни в стосунках і надання відповідних рекомендацій (наприклад, у форматі буклетів, інформаційних зустрічей тощо) здатні запобігти виникненню більшості проблем у родинах військовослужбовців, а своєчасне їх виявлення і корекція сприятимуть мінімізації їхнього впливу на психологічний стан військовослужбовців.

Перспективи подальших досліджень такі: 1) обгрунтування форм взаємодії з дружинами військовослужбовців і самими військовослужбовцями для запобігання сімейним проблемам; 2) емпіричне підтвердження ефективності впливу обраних форм роботи на зменшення негативного впливу сімейних стресорів.

\section{Список використаних джерел}

1. Інтерв'ю з начальником управління морально-психологічного забезпечення Генштабу ЗСУ). Інформаційне агентство "РБК”. (2018). Взято з https://daily. rbc.ua/rus/show/general-mayor-vsu-oleg-gruntkovskiy-okolo-1519946455.html.

2. Інтерв'ю з Міністром оборони України (2018). Інформаційний ресурс “Голос Америки”. Взято 3 https://ukrainian.voanews.com/a/stepan-poltorakinterviudzhaveliny/4237833.html.

3. Про внесення змін до Загального положення про центр соціальних служб для сім'ї, дітей та молоді. Постанова Кабінету Міністрів України № 528 від 19 липня 2017 р. Взято з http://zakon5.rada.gov.ua.

4. Дубчак, О. Д. (Ред.). (2017). Охорона психічного здоров'я в умовах війни. Пер. $з$ англ. Київ: Наш формат.

5. Стасюк, В. В. (2006). Психологія локальних війн та збройних конфліктів. Київ: НАОУ.

6. Лесков, В. О. (2008). Соціально-психологічна реабілітація військовослужбовиів із районів військових конфліктів. (Автореф. дис. канд. психол. наук). Національна академія Державної прикордонної служби України імені Богдана Хмельницького, Хмельницький.

7. Волошин, П. В., Шестопалова, Л. Ф., \& Підкоритов, В. С. (2002). Посттравматичні стресові розлади: діагностика, лікування, реабілітація. Харків. 
8. Буряк, О. О., Гіневський, М. І., \& Катеруша, Г. Л. (2015). Шляхи та методи реабілітації осіб з “військовим синдромом" та посттравматичним стресовим розладом. Збірник наукових праць Харківського університету Повітряних Сил, 3 (44), 137-141.

9. Агаев, Н. А., \& Флоранская, О. В. (2003). Проблема психологического обеспечения психического здоровья военнослужащих и членов их семей. Екологічна психологія в Украӥні. Взято $3 \mathrm{http}: /$ ecopsy.com.ua/data/zbirki/ 2003_01/sb01_01.pdf.

10. Дідик, Н. Ф. (2018). Соціально-психологічна підтримка членів родин військовослужбовців як чинник впливу на морально-психологічний стан бійця під час виконання завдань у зоні АТО. Украӥнський психологічний журнал, 1(7), 41-56.

11. Агаєв, Н. А., Кокун, О. М., Пішко, І. О., Лозінська, Н. С., Остапчук, В. В., \& Ткаченко В. В. (2016). Збірник методик для діагностики негативних психічних станів військовослужбовців. Київ: НДЦ ГП ЗСУ.

12. Кокун, О. М., Агаєв, Н. А, Пішко, І. О., \& Лозінська, Н. С. (2015). Особливості вияву негативних психічних станів у військовослужбовців внаслідок тривалої участі в бойових діях та перебування в зоні АТО. Вісник Національного університету оборони України, 3 (46), 123-129.

13. Попелюшко, Р. П. (2016). Причини виникнення та механізм розвитку ПТСР у комбатантів. International Scientific-Practical Conference Actual questions and problems of development of social sciences. Kielce: Holy Cross University, 95-98.

14. Figley, C. R. (1986). Traumatic stress the role of the family and social support system. Trauma and its wake. 2nd vol. NY.

\section{References}

1. Interviu $\mathrm{z}$ nachalnykom upravlinnia moralno-psykholohichnoho zabezpechennia Henshtabu ZSU [Interview with the Chief of Main Department of Moral and Psychological Support of the Armed Forces of Ukraine] (2018). Informatsiine ahentstvo "RBK" [RBC news agency]. Retrieved from https://daily.rbc.ua/rus/ show/general-mayor-vsu-oleg-gruntkovskiy-okolo-1519946455.html_(ukr).

2. Interviu z Ministrom oborony Ukrainy [Interview with the Minister of Defense of Ukraine] (2018). Informatsiinyi resurs "Holos Ameryky" [Information Resource "Voice of America"]. Retrieved from https://ukrainian.voanews.com/a/stepanpoltorak-interviudzhaveliny/4237833.html (ukr).

3. Pro vnesennia zmin do Zahalnoho polozhennia pro tsentr sotsialnykh sluzhb dlia simi, ditei ta molodi. Postanova Kabinetu Ministriv Ukrainy [Resolution of the Cabinet of Ministers of Ukraine "On Amendments to the General Provisions on the Center for Social Services for Family, Children and Youth”]. № 528 of 19 July 2017]. Retrieved from http://zakon5.rada.gov.ua (ukr).

4. Dubchak, O. D. (Red.). (2017). Okhorona psykhichnoho zdorovia v umovakh viiny [Protection of mental helth in war conditions]. Kyiv: Nash format Publ. (ukr).

5. Stasiuk, V. V. (2006). Psykholohiia lokalnykh viin ta zbroinykh konfliktiv: pidruchnyk dlia slukhachiv ta studentiv vyshchykh navchalnykh zakladiv [Psychology of local wars and armed conflict: a textbook for students of higher educational institutions]. Kyiv (ukr). 
6. Leskov, V. O. (2008). Sotsialno-psykholohichna reabilitatsiia viiskovosluzhbovtsiv iz raioniv viiskovykh konfliktiv [Social and psychological rehabilitation of servicemen from military conflicts places]. Abstract of Ph. D. dissertation. National Academy of the State Tax Service of Ukraine named after Bohdan Khmelnytsky, Ukraine, Khmelnytskyi (ukr).

7. Voloshyn, P. V., Shestopalova, L. F., \& Pidkorytov, V. S. (2002). Posttravmatychni stresovi rozlady: diahnostyka, likuvannia, reabilitatsiia [Post-traumatic stress disorder: diagnosis, treatment, rehabilitation]. Kharkiv (ukr).

8. Buriak, O. O., Hinevskyi, M. I., \& Katerusha, H. L. (2015). Shliakhy ta metody reabilitatsii osib z "viiskovym syndromom" ta posttravmatychnym stresovym rozladom [Ways and methods of rehabilitation of persons with "war syndrome" and post-traumatic stress disorder]. Zbirnyk naukovykh prats Kharkivskoho universytetu Povitrianykh Syl [Collection of scientific works of Kharkiv University of Air Forces], 3 (44), 137-141 (ukr).

9. Agaev, N. A., \& Floranskaya, O. V. (2003). Problema psikhologicheskogo obespecheniya psikhicheskogo zdorovya voyennosluzhashchikh i chlenov ikh semey [The problem of psychological maintenance of mental health of servicemen and members of their families]. Ekolohichna psykholohiia $v$ Ukraini [Ecological psychology in Ukraine]. Retrieved from http://ecopsy.com.ua/data/zbirki/ 2003_01/sb01_01.pdf (rus).

10. Didyk, N. F. (2018). Sotsialno-psykholohichna pidtrymka chleniv rodyn viiskovosluzhbovtsiv yak chynnyk vplyvu na moralno-psykholohichnyi stan biitsia pid chas vykonannia zavdan u zoni ATO [Social and psychological support of members of the military families as the factor influencing the moral and psychological state of the combatant in the period of accomplishing the tasks in the zone of ATO]. Ukrainskyi psykholohichnyi zhurnal [Ukrainian Psychological journal], 1(7), 41-56 (ukr).

11. Ahaiev, N. A., Kokun, O. M., Pishko, I. O., Lozinska, N. S., Ostapchuk, V. V., \& Tkachenko, V. V. (2016). Zbirnyk metodyk dlia diahnostyky nehatyvnykh psykhichnykh staniv viiskovosluzhbovtsiv [Collection of methods for diagnosing negative mental states of servicemen]. Kyiv (ukr).

12. Kokun, O. M., Ahaiev, N. A., Pishko, I. O., \& Lozinska, N. S. (2015). Osoblyvosti vyiavu nehatyvnykh psykhichnykh staniv u viiskovosluzhbovtsiv vnaslidok tryvaloi uchasti v boiovykh diiakh ta perebuvannia v zoni ATO [Features of the manifestation of negative mental states of servicemen as a result of prolonged participation in fighting and staying in ATO]. Visnyk Natsionalnoho universytetu oborony Ukrainy [Bulletin of the National University of Defense of Ukraine], 3 (46), 123-129 (ukr).

13. Popeliushko, R. P. (2016). Prychyny vynyknennia ta mekhanizm rozvytku PTSR $\mathrm{u}$ kombatantiv [Causes and mechanism occurence of PTSD in combatants]. International Scientific-Practical Conference Actual questions and problems of development of social sciences. Kielce: Holy Cross University, 95-98 (ukr).

14. Figley, C. R. (1986). Traumatic stress the role of the family and social support system. Trauma and its wake. 2nd vol. NY. 